\title{
From Input to Output: The Off-Campus Practice Teaching Experience
}

\author{
Lynn M. Besa, Edna P. Cabrera, and Arlene Grace C. Diaz
}

\begin{abstract}
Professional Education 13 or the Practice Teaching is the summit of the pre-service training of the aspiring educators. Thus, it is the period in which theories are applied in the actual classroom teaching where practice teachers are expected to be equipped with the necessary competencies in order to meet the challenges of the $21^{\text {st }}$ century ASEAN teaching profession.

Using both quantitative and qualitative analyses, this study aims to evaluate the actual teaching of the pre-service teachers through their cooperating teachers in the cooperating schools in Mandaluyong and Pasig Cities. The study aims to identify the level of competencies of the practice teachers in terms of knowledge, skills and attitude, determine the feedback of the cooperating schools, compare the level of competency of the practice teachers and related variables and identity the gaps between theory and practice to improve the quality of pre-service teaching.

The study reveals that the student teachers' level of competencies in knowledge, skills and affective domains were found to be outstanding based on the feedback of the cooperating schools. However, there is a significant difference between their level of competencies and specialization. Furthermore, the result disclosed that the dominant feedback of the cooperating schools among the practice teachers is commendable.
\end{abstract}

Index Terms-Cooperating teachers, competency levels, practice teaching, student teachers.

\section{INTRODUCTION}

Understanding teaching starts from developing a viable concept of teaching that goes beyond analyzing teaching methods and describing various activities that go into the process. A working teacher then must know what teaching is since his/her concept of teaching guides his/her behavior. His/her understanding of teaching serves as guide to all activities s/he and the learners will engage in. In other words, the patterns of behavior are determined by a teacher's concept of his/her role. In the same way, one's concept of teaching impacts his/her performance.

Teaching is viewed as organized, purposeful and deliberate efforts designed to bring about certain desirable ends in an individual [1]. In the $21^{\text {st }}$ century teaching-learning process the teacher must be equipped with the necessary qualifications imperative among the $21^{\text {st }}$ century learners. Thus, understanding teaching starts from developing a viable concept of teaching that goes beyond analyzing teaching methods and describing various activities

Manuscript received June 16, 2017; revised September 20, 2017.

The authors are with Rizal Technological University, Philippines (e-mail: besalynn@yahoo.com, epcabrera@yahoo.com,agc_diaz@yahoo.com). that go into the process.

The concept of constructivism or learning by doing aims to provide vicarious teaching experience among practice teachers. However, the gap between research and practice, as in most areas of education is prevalent. In the Philippines, to bridge the gap, the Philippine Normal University President during the 2014 ASEAN Teacher Education Conference mentioned that amidst the changing educational context in Southeast Asia as a result of the ASEAN vision to forge a common ASEAN community by 2015, the initiatives toward harmonization of standards in education, particularly in higher education are gradually being put in place [2].

Disappointingly, the shortage of the qualified teachers has been the major concern in the field of education in many countries. ASEAN is not an exception. Many teachers were/have been trained using different training formula (different geographical areas) and, as a result, their capacity is different. There is an imbalance in terms of providing knowledge, skills, and moral which enable them to effectively and fully participate in the country development as well as in building human resources for the nations. Qualifications of some teachers, teacher trainers and school managers are considered as inappropriate with the school level (new curriculum, textbook, and teaching materials) they are currently teaching/ working. Many in-service training courses are irregularly done and mostly in short courses and urgent for some countries in the region [3].

A person seeking to teach, to become professional, must not only develop refined skills in applied settings. Hand-in-hand with these skills, s/he must have an adequate knowledge of teaching models and teaching strategies [1]. Hence, in order for a teacher to be equipped, s/he has to finish first academic units in which general education, professional education, specialization, field study subjects are to be taken. While during the terminal year, s/he has to undergo practice teaching as the summit of the curricular year.

Practice teaching is a critical stage prior to graduation. In fact, the preparation of individuals to become competent teachers is one of the mandates of pre-service institutions [4], [5]. How ready are the student teachers or the commonly called pre-service teachers in their practice teaching? Do they have the necessary knowledge and skills imperative for $21^{\text {st }}$ century teaching? How do the cooperating teachers or the partner teachers who serve as mentors perceive their teaching performance?

This study aimed to evaluate the performance of the student teachers as to the application of what they learned during their academic years and their actual teaching in the cooperating schools where they are deployed. Specifically, the study intended to explore the level of competency of the practice teachers in terms of knowledge, skills and attitudes, 
solicit the feedbacks of the cooperating schools and identify the difference between the levels of competency of the practice teachers when grouped according to their specialization.

The preparation of individuals to become competent teachers is one of the mandates of pre-service institutions [4]. Thus, this study would be beneficial to the College of Education since, it highlights teacher education programs. This study would provide the faculty members of the inputs on the strength and weaknesses of the aspiring teachers so they could adjust their teaching objectives based on the demands of both the education system and University thrust. The study would also enlighten the student teachers of their own strength and weaknesses in order to meet the ASEAN teacher requirements and the $21^{\text {st }}$ century education. Moreover, the study aimed to contribute data in the Philippine education system to be more relevant to basic education reforms and current development initiatives by examining new paradigms of pre-service teacher education and their implications for practice, and explore emerging innovative practices as an important contribution to the field.

\section{PROCEDURE}

\section{A. Research Methods Used}

The study is generally descriptive in nature were survey and interview were specifically used as the research methods. The survey method was used to collect data, categorize the area of specialization and determine the level of competencies of the student teachers from the seven departments. The interview was used to get feedback from the cooperating schools. While the responses of the cooperating teachers on the performance of the student teachers were subjected to qualitative feedback analysis.

In the quantitative analysis of the data, a survey instrument from Appendix C Pre-Service Teacher's Actual Teaching Observation and Rating Sheet [6] and was subjected to statistical treatment such as frequency count, weighted mean and one-way ANOVA.

While in the interview part of the study, an unstructured/ informal interview was conducted during the consultation with the selected secondary teachers who handled student teachers during the second semester of the school year 2015-2016.

\section{B. Participants}

The selected secondary teachers who handled student teachers from both Pasig and Mandaluyong campuses during the SY 2015-2016 who evaluated the performance of the student teachers responded to the survey questionnaire and interview were the requested participants in the study.

While the student teachers were the subjects of the study. The student teachers were composed of the six majors. Namely English, Filipino, Math, Science, Filipino, Social Studies and Computer Education.

Out of the total population equivalent to 389, 206 student teachers or more than half of the population were selected using stratified random technique.

\section{RESUlTS AND DisCUSSIONS}

Pre-service education often provides the first step in the professional development of teachers. It exposes pre-service teachers to new perspectives as well as prepares them in knowledge and skills areas. Knowledge includes disciplinary content, or subject knowledge, and pedagogical content knowledge, or knowledge of how to teach which forms the basis for quality practice. While pedagogical knowledge can be defined as "...the content, skills, and strategies required for effective teaching". Pedagogical knowledge is linked closely to teacher belief in that there are factors that influence teachers' attitudes and beliefs toward the implementation of a variety of instructional models and strategies [7]

Teacher training institutions are missioned to train competitive educators for change and future schools. Teaching practice is a period of studies where the initial professional steps are made, the attitude towards teacher's activity, rights, obligations and responsibilities is shaped. It is the educational space where the quality of competencies acquired during the studies is revealed. Therefore, teaching practice should help pre-service teachers acquire professional competencies and experience necessary for practical activity. [8]

\section{COMPETENCY LeVEl of PRACTICE TeACHERS}

\section{A. Knowledge in: A Lesson Planning}

TABLE I: LEVEL OF COMPETENCY OF THE RESPONDENTS IN TERMS OF KNOWLEDGE IN LESSON PLANNING

\begin{tabular}{|c|c|c|}
\hline Knowledge in lesson planning & $\mathbf{W M}$ & VI \\
\hline A. Lesson plan is well prepared & 3.59 & Outstanding \\
\hline \multicolumn{3}{|l|}{ B. There is congruence between: } \\
\hline 1. objective and subject matter & 3.54 & outstanding \\
\hline 2. objective and teaching procedure & 3.59 & outstanding \\
\hline 3. objective and formative test & 3.55 & outstanding \\
\hline 4. objective and assignment & 3.54 & outstanding \\
\hline Average & 3.575 & outstanding \\
\hline
\end{tabular}

Table I shows that lesson plan is well prepared has 3.59 weighted mean and is interpreted as outstanding. Congruence between objectives and subject matter has 3.54 and is interpreted as outstanding, congruence between objective and teaching procedures has a weighted mean of 3.59 and is interpreted as outstanding. Congruence between objectives and formative test has a weighted mean of 3.55 and is interpreted as outstanding and congruence between objectives and assignment has a weighted mean of 3.54 and is interpreted as outstanding. In general, the average weighted mean is 3.575 and is interpreted as outstanding.

The result indicates that the average level of competency of the student teachers in lesson planning is outstanding. Thus, the result reveals that the respondents were perceived to be performing outstandingly in terms of lesson planning.

[9] cited that effective lesson plans are important as they allow a teacher to set specific student learning goals and identify the concrete steps and activities to achieve those aims. 


\section{B. Content}

TABLE II: LEVEL OF COMPETENCY OF THE RESPONDENTS IN TERMS OF CONTENT

\begin{tabular}{lcc}
\hline Knowledge of the Content & WM & VI \\
\hline $\begin{array}{l}\text { A. demonstrate in depth knowledge of the subject } \\
\text { matter }\end{array}$ & 3.59 & Outstanding \\
$\begin{array}{l}\text { B. is able to relate lessons to actual life situations } \\
\begin{array}{l}\text { C. keeps abreast of new ideas and understanding } \\
\text { in the field }\end{array}\end{array}$ & 3.55 & Outstanding \\
$\begin{array}{l}\text { D. gives sufficient and concrete examples to create } \\
\text { meaningful learning experiences }\end{array}$ & 3.51 & very \\
Average & 3.53 & Outstanding \\
\hline
\end{tabular}

Table II shows that the student teachers' demonstration of in-depth knowledge of the subject matter has a weighted mean of 3.59 and is interpreted as outstanding. The student teachers' able to relate lessons to actual life situations has a weighted mean of 3.55 and is interpreted as outstanding. The student teachers giving of sufficient and concrete examples to create meaningful learning experiences has a weighted mean of 3.51 and is interpreted as outstanding. While student teachers keeping abreast of new ideas and understanding in the field has 3.47 weighted mean and is interpreted as very satisfactory. In general, knowledge of the content has an average of 3.53 weighted mean and is interpreted as outstanding.

The table reveals that out of the four categories in the knowledge of content, only one area is categorized as very satisfactory while the rest of the categories are interpreted as outstanding. The findings disclose that the student teachers were able to carry with them the inputs they acquired and learned during their academic subjects in their pre-service training and are reflected in their practice teaching which proves that the student teachers possess a strong foundation in terms of the content.

\section{Skills in: A Teaching Methods}

TABLE III: COMPETENCY LEVEL IN TEACHING METHODS

\begin{tabular}{lcc}
\hline Skills in Teaching Methods & WM & VI \\
\hline $\begin{array}{l}\text { A. Method/s used was/were suited to the } \\
\text { needs and capabilities of the students }\end{array}$ & 3.61 & Outstanding \\
$\begin{array}{l}\text { B. The teacher was creative enough to adapt } \\
\text { his/her method to students' capabilities }\end{array}$ & 3.53 & Outstanding \\
$\begin{array}{l}\text { C. Instructional materials were used to } \\
\text { illustrate the lesson }\end{array}$ & 3.51 & Outstanding \\
$\begin{array}{l}\text { D. The teacher made effective use of the } \\
\text { formative test during teaching }\end{array}$ & 3.53 & Outstanding \\
Average & 3.55 & Outstanding \\
\hline
\end{tabular}

Table III shows that student teachers methods used/ was/were suited to the needs and capabilities of the students has a weighted mean of 3.61 and is interpreted as outstanding. The student teachers were creative enough to adapt their method to students' capabilities has a weighted mean of 3.53 and is interpreted as outstanding. The student teachers' instructional materials were used to illustrate the lesson has a weighted mean of 3.51 and is interpreted as outstanding. The student teachers made effective use of the formative test during teaching has a weighted mean of 3.53 and is interpreted as outstanding.

Generally, the student teachers were found to have an outstanding skill in teaching methodology as reflected in the average weighted mean of 3.55 .

The result reveals that the student teachers possess the capacity to select the best approach which will work well for them and their learners. They were able to employ a variety of approaches and the best that fits their personal style. Thus, having a clear methodology outlines directions and procedures which tend to increase consistency [10]. Thus, learning is enhanced and made effective through proper selection of instructional approaches and methods.

\section{Classroom Management}

TABLE IV: COMPETENCY LEVEL IN CLASSROOM MANAGEMENT

\begin{tabular}{|c|c|c|}
\hline Competency Level in Classroom Management & WM & VI \\
\hline 1. attendance & 3.58 & Outstanding \\
\hline 2. assignment/homework/ agreement & 3.55 & Outstanding \\
\hline 3. practice exercises & 3.52 & Outstanding \\
\hline 4. group work/ projects & 3.53 & Outstanding \\
\hline 5. passing in and out of the room & 3.43 & $\begin{array}{c}\text { Very } \\
\text { satisfactory }\end{array}$ \\
\hline 6. correcting, distributing, and collecting paper & 3.56 & Outstanding \\
\hline $\begin{array}{l}\text { B. Order and discipline were present in the } \\
\text { classroom }\end{array}$ & 3.54 & Outstanding \\
\hline $\begin{array}{l}\text { C. Instructional materials were easy reach of the } \\
\text { teacher during his/her teaching }\end{array}$ & 3.51 & Outstanding \\
\hline Average & 3.53 & Outstanding \\
\hline
\end{tabular}

The table presents that the student teachers competency in checking attendance has a weighted mean of 3.58 and is interpreted as outstanding. Their competency in checking assignment/ homework/ agreement has a weighted mean of 3.55 and is interpreted as outstanding. The practice of exercises has a weighted mean of 3.52 and is interpreted as outstanding. The student teachers' facility of group works/ projects has a weighted mean of 3.53 and is interpreted as outstanding. Their passing in and out of the classroom has a weighted mean of 3.43 and is interpreted as very satisfactory. Their correcting, distributing and collecting of papers has a weighted mean of 3.56 and is interpreted as outstanding. Order and discipline were present in the classroom has a weighted mean of 3.54 and is interpreted as outstanding. Instructional materials were easy reach of the teacher during his/her teaching has a weighted mean of 3.51 and is interpreted as outstanding. While the student teachers average weighted mean is 3.53 and is interpreted as outstanding.

The result discloses that the student teachers portrayed an outstanding performance in classroom management. Hence, they were able to develop the necessary skills adequate to facilitate classroom tasks and to adequately sequence and pace subtasks to meet the students' leaning needs [9].

[11] cited that one of the essential elements is teaching competence is by creating and maintaining an orderly, productive classroom environment. [12] added that teachers who strive for excellence will incorporate a vast array of behavior management approaches in order that all children are engaged in a meaningful learning environment.

\section{E. Questioning Skills}

Table $\mathrm{V}$ shows that the teachers questioning skill in probing for learners' understanding has a weighted mean of 3.50 and is interpreted as outstanding. Their skill in helping students' articulate ideas and thinking process has a weighted mean of 3.54 and is interpreted as outstanding. Student 
teachers' promotion of risk-taking and problem solving has a weighted mean of 3.51 and is interpreted as outstanding. Their facility of factual recall has a weighted mean of 3.56 and is interpreted as outstanding. Their encouragement of convergent and divergent thinking has a weighted mean of 3.45 and is interpreted as very satisfactory. Their stimulation of curiosity has a weighted mean of 3.53 and is interpreted as outstanding. Their helping students to ask questions has a weighted mean of 3.57 and is interpreted as outstanding. The average mean is 3.53 and is interpreted as outstanding.

TABLE V: COMPETENCY LEVEL OF THE RESPONDENTS IN QUESTIONING SKILLS

\begin{tabular}{|c|c|c|}
\hline $\begin{array}{l}\text { Competency level of the respondents in } \\
\text { questioning skills }\end{array}$ & WM & VI \\
\hline \multicolumn{3}{|c|}{$\begin{array}{l}\text { The teacher's questioning skill such as the following stimulates discussion } \\
\text { in different ways: }\end{array}$} \\
\hline 1. probing for learner's understanding & 3.50 & Outstanding \\
\hline $\begin{array}{l}\text { 2. helping students articulate their ideas and } \\
\text { thinking process }\end{array}$ & 3.54 & Outstanding \\
\hline 3. promoting risk-taking and problem solving & 3.51 & Outstanding \\
\hline 4. facilitating factual recall & 3.56 & Outstanding \\
\hline $\begin{array}{l}\text { 5. encouraging convergent and divergent } \\
\text { thinking }\end{array}$ & 3.45 & $\begin{array}{l}\text { Very } \\
\text { satisfactory }\end{array}$ \\
\hline 6. stimulating curiosity & 3.53 & Outstanding \\
\hline 7. helping students to ask questions & 3.57 & Outstanding \\
\hline Average & 3.52 & Outstanding \\
\hline
\end{tabular}

Part of the good teaching is effective questioning. The learning process and effective instruction are both anchored on the art of questioning. Skillful questioning can elicit the correct response from learners, arouse their curiosity, stimulate their imagination, and motivate them to engage in the lesson and the particular learning experiences that form part of the learning tasks. When questions are defective, they cease to make learners think; their thoughts are muddled; and they do not feel challenged at all [9].

\section{F. Attitude (Personality)}

TABLE VI: COMPETENCY LEVEL IN TERMS OF TEACHERS' PERSONALITY

\begin{tabular}{lcc}
\hline Teachers attitude in terms of personality & WM & VI \\
\hline $\begin{array}{l}\text { A. The teacher is neat and well-groomed } \\
\text { B. The teacher is free from mannerisms that } \\
\text { tend to disturb the student's attention }\end{array}$ & 3.60 & $\begin{array}{c}\text { Outstanding } \\
\text { Very } \\
\text { satisfactory }\end{array}$ \\
$\begin{array}{l}\text { C. The teacher's personality is strong enough } \\
\text { to command respect and attention }\end{array}$ & 3.59 & Outstanding \\
$\begin{array}{l}\text { D. The teacher shows dynamism and } \\
\text { enthusiasm }\end{array}$ & 3.59 & Outstanding \\
$\begin{array}{l}\text { E. The teacher has well- modulated voice } \\
\text { Average }\end{array}$ & $\begin{array}{l}3.52 \\
\mathbf{3 . 5 4}\end{array}$ & $\begin{array}{l}\text { Outstanding } \\
\text { outstanding }\end{array}$ \\
\hline
\end{tabular}

Table VI divulges that the student teachers are neat and well-groomed has a weighted mean of 3.60 and is interpreted as outstanding. The student teachers are free from mannerisms that tend to disturb the students' attention has a weighted mean of 3.42 and is interpreted as very satisfactory. The teachers' personality is strong enough to command respect and attention and the teachers show dynamism and enthusiasm have the same weighted mean of 3.59 and is interpreted as outstanding. The teachers have well-modulated voice has 3.52 weighted mean and is interpreted as outstanding. The average weighted mean of the student teachers' competency level in terms of attitude which is coursed through teachers' personality is 3.52 and is interpreted as outstanding.
The result indicates that the student teachers' attitude which is articulated through personality traits is already expected since student teachers were trained to be groomed and proper before their students. Hence, norms in terms of posture, voice modulation, gestures including their energy in teaching had been subjected to rigid training during their pre-service.

It is evident that student teachers were able to apply basic concepts from their professional education subjects especially those subjects which involves preparation and evaluation of instructional materials, principles in teaching, social dimensions in education etc. in their practice teaching.

\section{FEedBACKS OF THE COOPERATING SCHOOLS AMONG THE PRE-SERVICE TEACHERS}

Majority of the cooperating schools commented that the student teachers from Rizal Technological University (RTU) are better performers. They said that RTU student teachers are diligent, industrious, obedient, flexible and willing to learn. Hence, they prefer RTU student teachers. They even cited that RTU student teachers have very good and pleasing personality, knowledge in lesson planning and content and are skillful in terms of methods and classroom management.

However, there are [still] comments for improvements which are attributed to the small number of student teachers.

\section{DIFFERENCE BETWEEN THE LEVEL OF COMPETENCY OF THE PRACTICE TEACHERS AND THEIR SPECIALIZATION}

TABLE VII: F-VALUE OBTAINED BETWEEN LEVEL OF COMPETENCIES AND SPECIALIZATION

\begin{tabular}{|c|c|c|c|}
\hline F- Value & F Critical Value & Decision & Interpretation \\
\hline 16.656 & 2.477 & $\begin{array}{c}\text { Reject Null } \\
\text { hypothesis }\end{array}$ & $\begin{array}{c}\text { Significant } \\
\text { difference }\end{array}$ \\
\hline
\end{tabular}

It could be gleaned that since the $16.656 \mathrm{~F}$-value is greater than the $2.477 \mathrm{~F}$ critical value, the null hypothesis is accepted at .05 level of significance. Therefore, there is a significant difference between the level of competencies and the area of specialization. The level of competencies in each major vary. The result further demonstrates that the difference may be the effect of the varied treatment per area of specialization and different subject teachers.

\section{CONCLUSION}

Pre-service teacher preparation programs with strong structure, coursework, and field experiences are crucial to preparing future teachers [13]. Thus, pre-service programs are important to consider when designing or reforming teacher training. The experience of the practice teachers in the actual teaching field provides them with knowledge about themselves, prepares them to find solutions in difficult teaching situations, analyzes questions and problems that may arise during their activities. Their experience is essential in their future work as teachers [14].

In the study, it was found that the student teachers level of competency is found to be outstanding. Furthermore, the student teachers were perceived to be fully equipped for their 
practice teaching. The student teaching performance indicates that they have strong foundation in the pre-service training which is supported by the commendable feedback of the cooperating teachers. Although there are some minor comments which requires attention for improvement, the overall feedback about the student teachers' performance is laudable.

In sum, the student teachers' attitude towards profession is creditable. Thus, they have strong foundation in terms of mastery of the content, lesson planning, teaching strategies and classroom management.

Therefore, to sustain the quality of education, the researchers recommend continuous enhancement of the programs so as not only to maintain but to catch up with the global requirements and demands of $21^{\text {st }}$ century teaching environment. Innovations and wider exposure even in multicultural environment to provide maximum teaching experience is highly encouraged. Moreover, personality and values formation activities should be strengthened to mold the student teachers towards teachers- expected character.

\section{ACKNOWLEDGMENT}

The researchers would like to thank all authorities in education who had been very influential and helpful in the completion of this study. The researchers would also like to thank Rizal Technological University as the place setting of the study.

\section{REFERENCES}

[1] A. Gaudencio, "Teaching models, strategies and skills," Rex Bookstore: Manila, 1997.

[2] B. O. Ester, "The challenge of harmonization of teacher education curriculum and programs in the ASEAN region," presented at ASEAN Teacher Education Conference 2014, Manila, Philippines.

[3] S. Sieng, "Challenge of equity and inclusiveness for teacher education in ASEAN," presented at ASEAN Teacher Education Conference 2014 Manila, Philippines.

[4] RA 7784. An act to strengthen teacher education in the Philippines by establishing centers of excellence, creating a teacher education council for the purpose, appropriating funds therefor, and for other purposes. [Online]. Available: http://www.gov.ph/1994/08/04/republic-act-no-7784/

[5] CMO 30 S. (2004). Revised policies and standards for undergraduate teachers education curriculum. [Online]. Available: http://www.dlsu.edu.ph/offices/iaa/downloads/iaa-cmo-no-30-series-2 004.pdf

[6] L. B. Milagros and H. G. L. Borabo, "My practice teaching handbook and portfolio," Quezon City: Lorimar Publishing, 2015.

[7] C. Sylvia et al., "Pre-service teachers' beliefs, attitudes and expectations: A review of the literature," National Institute of Education, Nanyang Technological University.

[8] R. Asta et al., "Experience in teaching practice of pre-service teachers: Analysis of written reflections," Procedia-Social and Behavioral Sciences 191, 2015, pp. 1048-1053.
[9] A. Victoria et al., 2015, "Principles of teaching 1," Rex Printing Company, Inc.: Quezon City.

[10] What is methodology? [Online]. Available: http://www.wisegeek.com/what-is-methodology.htm.

[11] D. O. LaCaze et al., "Classroom behavior and management for teachers," National Forum of Teacher Education Journal, vol. 22, no. 3, pp. 1-3, 2012.

[12] B. R. Dennis and M. A. A. Bacabac, "Teaching proficiency and preparedness of pre-service secondary mathematics teachers: Its implications to actual practice," American Journal of Educational Research, vol. 4, no. 16, 2016, pp. 1184-1190.

[13] K. K. Monika. (2014). Pre-service teacher education and classroom management: An evaluation of education. [Online]. Available: https://tspace.library.utoronto.ca/bitstream/1807/43994/1/Klopfer_Kri stina_M_201403_MA_thesis.pdf\%20.pdf

[14] S. Anu and E. Viskus, "Reflection on teaching: A way to learn from practice," Procedia-Social and Behavioral Sciences 191, 2015, pp. 1941-1946.

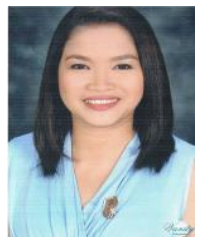

Lynn M. Besa was born in Tarlac, Philippines. She has finished her bachelor of secondary education as Cum laude at Rizal Technological University where she also finished her masters of arts major in education in language instruction. She is a candidate for Ph.D in applied linguistics at Philippine Normal University.

She was the former head of the English Department and head staff of the Office of the vice president for development and administration. She is a fulltime faculty of the College of Education where she teaches English, education and research subjects.

Prof. Besa is a member of different language, literature, education and research organizations both local and abroad. She had co-authored book in literatures and had presented and published researches in international journals.

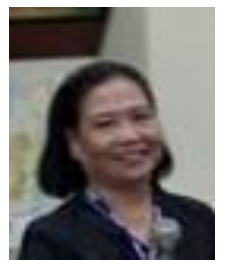

Edna P. Cabrera was born in Manila, Philippines. She graduated as the bachelor of science in chemistry as University Scholar in Pamantasan ng Lungsod ng Maynila in 1977 and had finished her masters of arts major in industrial psychology in Rizal Technological University in 2005.

She has served as secondary school teacher from 1979-present. She had been the assistant principal in Jose Rizal College, student coordinator, guidance councilor, club adviser and science department head in Rizal University. At present, she is the supervising head of the Student Teachers in RTU.

Prof. Cabrera is a member of different associations such as Philippine Association for Teachers and Educators, Asia Pacific Consortium of Researchers and Educators, Inc. and Philippine Association for the Advancement of Science and Technology. She also co-authored the National Service Training Program (NSTP) Workbook for RTU students.



Arlene Grace C. Diaz was born in Sta. Mesa Manila, Philippines. She has finished her bachelor of computer engineering, masters of arts in instructional technology and the Ph.D in technology education at Rizal Technological University.

From 1985 to present, he has served her Alma Mater as full time faculty member, department head and extension director. At present, she is the dean of the

College of Education.

Dr. Diaz is an active member of different education and computer organizations. She co-authored books in information technology and has conducted researches in computer education and practice teaching. 